\title{
Microsatellite multiplex systems for Brycon orbignyanus (Characiformes: Bryconidae)
}

\author{
L.C. Carvalho ${ }^{a}$, J.M. Ribeiro ${ }^{a}$ and G.M. Yazbeck ${ }^{a *}$ \\ aLaboratório de Recursos Genéticos, Departamento de Zootecnia, Universidade Federal de São João Del Rei - UFSJ, \\ Campus Tancredo de Almeida Neves, Praça Frei Orlando, 170, CEP 36307-352, São João Del-Rei, MG, Brasil \\ *e-mail:dna@ufsj.edu.br
}

Received: March 06, 2018 - Accepted: June 12, 2018 - Distributed: November 30, 2019

The Neotropical migratory (piracema) fish species Brycon orbignyanus (Valenciennes, 1850), commonly known as piracanjuba, was once considered one of the most conspicuous resources for fisheries in the La Plata River Basin, the second largest in South America, but today is considered a threatened species, almost extinct in the wild (Machado et al., 2008; Oliveira et al., 2017). It suffers from several pressures such as intense hydroelectric exploitation in the basin, pollution, deforestation of riverine vegetation and introduction of species (Oliveira et al., 2017). Its omnivorous habits and fast growth curve under domestication (Sipaúba-Tavares et al., 2008; Nogueira et al., 2014) makes this fish a good candidate for the development of aquaculture programs, which could guarantee its ex situ cultivation and help in situ conservation initiatives. Hatchery production of this species, targeting stocking efforts in areas affected by dam introduction, is presumed to be important in helping maintaining small population remnants in some isolated points in the basin, but this is still unaddressed in rigorous scientific studies. Such scenario brings about the importance of the development of tools for the rapid assessment of genetic diversity and structure, in order to identify the impacts over dwindling stocks and to evaluate the efficiency of fish stocking activities, in this important species.

Microsatellite markers are considered useful and effective tools for these purposes and have been demonstrated to be efficient in stock selection and reintroduction programs (e.g. Attard et al., 2016). B. orbignyanus could benefit from the development of advanced breeding and rearing technologies, in which microsatellite diversity assessment systems could be valuable resources (Lopera-Barrero, 2009). Despite its status, species-specific microsatellite markers were lacking in B. orbignyanus until recent years, which led to the use of heterologous loci for breeding, genetic diversity and conservation studies in this species (e.g. Rodriguez-Rodriguez et al., 2010; Lopera-Barrero et al., 2010, 2014; Ashikaga et al., 2015; Carmo et al., 2015; Castro et al., 2017). This yields a restricted number of usable loci and can lead to increasing artefactual noise in the analyses (Carmo et al., 2015).With the unveiling of the first 29 microsatellite loci from $B$. orbignyanus (Arias et al., 2016), by the application of next-generation sequencing (NGS) pipelines (Yazbeck et al., 2018), more reliable genetic analysis systems for this species can now be developed, in order to accelerate the profiling of extant and cultivated stocks in this threatened species. Recently, seven polymorphic microsatellite loci were also developed by means of traditional cloning methods, involving a microsatellite-enriched library prepared with hybridization capture process, and their transferability assayed, along five other new markers, in Brycon gouldingi and B. falcatus (Souza et al., 2018).

Combining (i.e. multiplexing) polymerase chain reactions (PCR) of different loci, simultaneously into a single assay, provides the advantage of making the process more economically efficient. Multiplex systems of microsatellite loci are particularly useful for making it practical to perform parentage analysis in fish, an important step in the evaluation of the efficiency of stock supplementation, selective breeding programs and hatchery management (Abdul-Muneer, 2014; Yue and Xia, 2014). Here we present the design, development and validation of microsatellite multiplexes for B. orbignyanus.

Candidate multiplex systems were evaluated from the group of microsatellite markers described in Arias et al. (2016). For combined primers selection we developed an in-house program, written in Python, based on graph theory, with the aid of the igraph library to automatically sort markers based on its reported range of fragment amplification length: each microsatellite marker is represented as a vertex in the graph and pairs of markers bearing mutually exclusive observed amplification ranges being connected by edges. This permitted us to create lists of possible compatible sets of primers. Further, this compatibility was verified with Primer3 (Untergasser et al., 2012) to avoid heterodimers and used as a further criterion to select putative marker groups for empirical testing. We newly analyzed the extracted DNA from a subsample of 36 individuals, out of the 49 present in Arias et al. (2016). We used the initial PCR conditions for each individual DNA marker, described in the supplemental information for B. orbignyanus-Electronic Supplementary Material 16 - in Arias et al. (2016), and tested the multiplex systems by doubling buffer concentration, adding TBT (Trealose-BSA-Tween 20 - Samarakoon et al., 2013), assaying varying primers and $\mathrm{MgCl}_{2}$ concentrations, following the guidelines presented in Green and Sambrook (2012).

The empirical test for each proposed multiplex system included the elimination of loci which, despite being theoretically compatible in range of amplified fragment 
size, resulted in unspecific amplification of stutter or ghost bands, confusing straight genotyping. Each reaction was standardized with an annealing temperature of $50^{\circ} \mathrm{C}, 1 \mathrm{U}$ of Taq DNA polymerase and a final concentration of $0.1 \mathrm{mM}$ of dNTPs; $100 \mathrm{mM} \mathrm{KCl} ; 25$ mM Tris- $\mathrm{HCl} \mathrm{pH}$ 8.4; 0.2\% Triton X-100; $300 \mathrm{mM}$ trehalose; $400 \mu \mathrm{g} / \mathrm{ml}$ nonacetylated BSA and $0.4 \%$ Tween-20 for a multiplex volume of $10 \mu \mathrm{l}$. This was followed by adjustments in primers and enzymatic co-factor $\left(\mathrm{Mg}^{++}\right)$concentrations. Amplification results were resolved using polyacrylamide gel electrophoresis (PAGE), using $10 \%$ gels and applying $4.5 \mathrm{~V} \cdot \mathrm{cm}^{-1}$, for $15 \mathrm{~h}$. Conformity with Hardy-Weinberg Expectations (HWE) was verified with the exact test implemented on Genepop, according to a Holm-Bonferroni significance correction and other general variability descriptors (number of alleles, observed and expected heterozygosity, locus inbreeding coefficient, Shannon's information index) were assessed with GenAlex.

A set of six individual PCR assays, biplexes and triplexes, including a total of 16 different $B$. orbignyanus microsatellite loci (multiplexes 1 through 6) were developed and tested (as shown in Table 1). Genetic diversity results were obtained through its application in a broodstock sample (as shown in Table 2). The observed number of alleles ranged from 2 to 9 , the expected heterozygosity varied from 0.24 to 0.86 , and Shannon information's index ranged from 0.41 to

Table 1. Microsatellite multiplex systems for B. orbignyanus. Table shows the concentrations of variable components for PCR $\left(\mathrm{MgCl}_{2}\right.$ and each primer $), \mathrm{Na}=$ Number of alleles.

\begin{tabular}{|c|c|c|c|c|c|c|c|}
\hline System & Locus & $\begin{array}{l}\text { GenBank } \\
\text { accession }\end{array}$ & $\begin{array}{c}\text { Repeat } \\
\text { sequence }\end{array}$ & $\begin{array}{c}\mathrm{MgCl}_{2} \\
(\mathrm{mM}) \\
\end{array}$ & $\begin{array}{c}\text { Primer } \\
(\mathrm{mM})\end{array}$ & $\begin{array}{l}\text { Expected/observed range } \\
\text { of product length (bp) }\end{array}$ & $\mathbf{N a}$ \\
\hline \multirow[t]{3}{*}{ Multiplex 1} & Borb01 & KT827795 & ATCT & 2.5 & 0.25 & $100-135$ & 8 \\
\hline & Borb25 & KT827811 & $\mathrm{AC}$ & & 0.25 & $262-318$ & 9 \\
\hline & Borb33 & KT827815 & $\mathrm{AC}$ & & 0.15 & $68-83$ & 3 \\
\hline \multirow[t]{3}{*}{ Multiplex 2} & Borb04 & KT827796 & ATAG & 3 & 0.1 & $118-123$ & 2 \\
\hline & Borb11 & KT827801 & ATT & & 0.25 & $147-178$ & 8 \\
\hline & Borb39 & KT827820 & $\mathrm{AC}$ & & 0.25 & 94-101 & 2 \\
\hline \multirow[t]{3}{*}{ Multiplex 3} & Borb07 & KT827798 & ATA & 2.5 & 0.25 & $142-152$ & 4 \\
\hline & Borb30 & KT827814 & $\mathrm{CA}$ & & 0.15 & $79-89$ & 4 \\
\hline & Borb46 & KT827823 & $\mathrm{CA}$ & & 0.25 & $121-131$ & 3 \\
\hline \multirow[t]{3}{*}{ Multiplex 4} & Borb08 & KT827799 & ATT & 2.5 & 0.25 & $114-140$ & 8 \\
\hline & Borb15 & KT827805 & ATT & & 0.25 & $147-179$ & 9 \\
\hline & Borb24 & KT827810 & $\mathrm{AC}$ & & 0.15 & 96-104 & 4 \\
\hline \multirow[t]{2}{*}{ Multiplex 5} & Borb09 & KT827800 & AAT & 3.5 & 0.35 & $126-144$ & 5 \\
\hline & Borb36 & KT827818 & $\mathrm{AG}$ & & 0.35 & 89-109 & 6 \\
\hline \multirow[t]{2}{*}{ Multiplex 6} & Borb17 & KT827807 & ATA & 3.5 & 0.35 & $131-151$ & 6 \\
\hline & Borb44 & KT827822 & $\mathrm{AG}$ & & 0.35 & $88-110$ & 5 \\
\hline
\end{tabular}

Table 2. Diversity results from the new B. orbignyanus microsatellite multiplexes.

\begin{tabular}{cccccccc}
\hline System & Locus & I & Ho & He & F & P-value & HWE \\
\hline Multiplex 1 & Borb01 & 1.81 & 0.47 & 0.81 & 0.42 & 0.0000 & No \\
& Borb25 & 1.95 & 0.97 & 0.81 & -0.19 & 0.0329 & Yes \\
& Borb33 & 0.77 & 0.47 & 0.44 & -0.08 & 0.2916 & Yes \\
Multiplex 2 & Borb04 & 0.41 & 0.23 & 0.24 & 0.07 & 0.5261 & Yes \\
& Borb11 & 1.90 & 0.66 & 0.83 & 0.21 & 0.0006 & No \\
& Borb39 & 0.49 & 0.33 & 0.31 & -0.06 & 1 & Yes \\
Multiplex 3 & Borb07 & 1.11 & 0.19 & 0.63 & 0.69 & 0.0000 & No \\
& Borb30 & 1.33 & 0.28 & 0.72 & 0.61 & 0.0000 & No \\
Multiplex 4 & Borb46 & 0.99 & 0.19 & 0.59 & 0.67 & 0.0000 & No \\
& Borb08 & 1.77 & 0.58 & 0.79 & 0.26 & 0.0008 & No \\
& Borb15 & 2.07 & 0.41 & 0.86 & 0.53 & 0.0000 & No \\
Multiplex 5 & Borb24 & 0.99 & 0.44 & 0.52 & 0.14 & 0.0650 & Yes \\
& Borb09 & 1.28 & 0.64 & 0.65 & 0.02 & 0.0588 & Yes \\
Multiplex 6 6 & 1.62 & 0.53 & 0.78 & 0.32 & 0.0000 & No \\
& Borb17 & 1.66 & 0.61 & 0.79 & 0.22 & 0.0108 & Yes \\
\hline
\end{tabular}

$\mathrm{I}=$ Shannon's Information Index; Ho=Observed heterozygosity; He=Expected heterozygosity; F=Fixation index; P-value=exact probability value; HWE=Hardy-Weinberg Expectations. 
2.07, respectively for marker Borb04 present in Multiplex 2 and marker Borb15, from Multiplex 4. Most pronounced value of F (Sewall Wright's inbreeding coefficient) was found at locus Borb07, followed by Borb46, Borb30, Borb15 and Borb01. Half the multiplexed loci conformed to the Hardy-Weinberg expectations in the sample, after a Holm-Bonferroni significance correction $(\alpha=0.0008)$.

The six combinations of molecular DNA markers for performing multiplex microsatellite PCR in $B$. orbignyanus validated here encompass around $44 \%$ of all specific polymorphic microsatellites so far validated for this species (Arias et al., 2016; Souza et al., 2018). These multiplex systems potentially increase the rate the genetic analysis of these 16 loci in approximately 2.5 times (i.e. 16 markers in six reactions) and provide the first multiplex class of specific DNA markers for B. orbignyanus. The results found on the diversity analysis of the multiplex sets reveal a similar pattern as observed in Arias et al. (2016), which analysed more fish ( $\mathrm{N}=49)$ and more markers $(\mathrm{N}=29)$. Only a single allele (\#03) was not detected at one locus (Borb07), due to the smaller sample analyzed here $(\mathrm{N}=36$ fish). Lack of conformation with HWE is probably due to stock genetic substructuring, because of broodstock formation, which typically draws from alternative population sources, leading to a pronounced Wahlund effect (all deviations are due to excess of homozygous genotypes). Besides, it has been argued that purging data for the lack of HWE conformation (when the cause is not a PCR artifact) can do more harm than good (e.g. Allendorf et al., 2013). Future full families tests can screen out fortuitous null alleles. Our systems balance both class of loci and presents four times more markers than in a conservation genetics analysis recently carried out in this fish (Ashikaga et al., 2015). Taken together, these results attest to the systems' usefulness in genetic diversity studies and applications.

The development of multiplex systems in PAGE, rather than capillary electrophoresis (CE), severely hampers the assembling of assays accumulating more loci in a single reaction (e.g. Wang et al., 2016). Nevertheless, it favors the use of loci with amplified fragment profile promptly detectable with the use of simple electrophoresis rigs, generally available to small laboratories and easily adaptable to hatchery operations.

Although radically new alternative approaches have been recently revealed for the massively parallel screening of microsatellite loci, conjugating CRISPR-Cas 9 and NGS technologies (Shin et al., 2017) - along with its promised dramatic drop in the cost of molecular variability analysis in non-model species - PCR based marker screening will still provide a way for rapid access of genetic information in simple laboratories, hatcheries and conservation initiatives focusing on piracanjuba.

The multiplex systems presented here constitute the first combined specific PCR markers for this important Neotropical fish. It will assist in alleviating labor and reducing material costs of routine DNA analysis in B. orbignyanus.

\section{Acknowledgements}

We would like to thanks Andréa Doria Okada Guimarães Garcia who assisted the authors in this project, Fundação de Amparo à Pesquisa de Minas Gerais (FAPEMIG) Programa Primeiros Passos na Ciência, Conselho Nacional de Pesquisa e Tecnologia (CNPq) and Companhia Energética de Minas Gerais (CEMIG). We disclose a potential conflict of interests by declaring that the authors have applied for a patent (pending) at INPI (BR10201700635) with the findings of this study.

\section{References}

ABDUL-MUNEER, P.M., 2014. Application of microsatellite markers in conservation genetics and fisheries management: recent advances in population structure analysis and conservation strategies. Genetics Research International, vol. 2014, pp. 1-11. http://dx.doi.org/10.1155/2014/691759.

ALLENDORF, F.W., LUIKART, G. and AITKEN, S.N., 2013. Conservation and the genetics of populations. 2nd ed. Oxford: Wiley-Blackwell. $622 \mathrm{p}$

ARIAS.; AULAGNIER, S.; BAERWALD, E.F.; BARCLAY, R.M.R.; BATISTA, J.S.; BEASLEY, R.R.; BEZERRA, R.A.; BLANC, F.; BRIDGE, E.S.; CABRIA, M.T.; CAPUTO, L.I.; CHEN, J.; CHEN, J.-H.; CHEN, Z.; CHEN, C.-H.; CHU, P.; CONTINA, A.; DA SILVA CARMO, F.M.; DE CARVALHO, L.C.; DE FREITAS VIANA, P.M.; DE MACÊDO, J.L.V.; DE MENEZES YAZBECK, G.; DE OLIVEIRA TEIXEIRA, Z.; DE SOUZA ARAUJO, N.; DEQUIGIOVANNI, G.; DING, S.; DOS SANTOS, P.K.F.; ERNEST, H.B.; FENG, Y.-W.; FORMIGA, K.M.; FOURNIER-CHAMBRILLON, C.; FRANÇOSO, E.; FU, Y.; GAGNE, R.B.; GAIOTTO, F.A.; GAO, T.; GE, H.; GE, T.; GILLET, F.; GONG, Y.; GONG, H.; GUO, Q.; GUO, L.; GUO, L.; HARRIGAN, R.J.; HE, L.; HOUSE, C.J.; DER HSIAO, C.; HUANG, R.; IYENGAR, A.; JIANG, X.; JIANG, H.-L.; JOHNSON, T.A.; JONES, K.L.; KAGEYAMA, P.Y.; KELLY, J.F.; LAM, L.; LANCE, S.L.; LI, H.; LI, C.; LI, F.; LI, H.; LI, S.; LI, Y.; LI, M.; LI, M.; LI, F.; LI, W.; LI, J.; LI, J.; LI, X.; LIANG, K.; LIANG, Y.; LIAO, F.; LIAO, L.; LIN, H.; LIN, H.; LIN, H.; LIN, Q.; LIU, H.; LIU, H.; LIU, L.; LIU, X.-Q.; LIU, P.; LIU, C.; LIU, X.; LOPES, M.T.G.; LU, D.; LUAN, M.-B.; LUO, W.; MENG, Z.; MENG, Z.; MICHAUX, J.R.; NÉMOZ, M.; POLLINGER, J.P.; QIAO, Y.; QU, H.; RAMOS, S.L.F.; LE ROUX, S.; SANTIAGO, L.R.; SHAO, X.; SHEN, K.-N.; SHEN, H.; SHEN, H.; SMITH, T.B.; SONG, D.; SOURP, E.; SUN, Y.; TANG, H.; TANG, Q.; TONG, Y.; VAN DEN EINDEN, M.; VAN HOPPE, M.J.C.; VEASEY, E.A.; VIAL-NOVELLA, C.; WAN, L.; WANG, X.; WANG, Y.; WANG, Y.; WANG, Y.; WANG, R.; WANG, X.; WANG, R.; WANG, Q.; WANG, G.; WANG, J.; WANG, D.; WANG, P.; WEI, X.-M.; WEN, Y.; WEN, H.; WU, X.-P.; WU, X.; XIANG, J.; XIE, Z.; XU, Z.; XU, P.; YANG, Z.; YANG, S.; YANG, S.; YIN, C.; YIN, S.; YIN, S.; YU, Y.; YUAN, X.; YUE, G.H.; ZANG, G.-G.; ZARDOYA, R.; ZHANG, L.; ZHANG, X.; ZHANG, Y.; ZHANG, G.; DI ZHANG, Y.; ZHANG, H.; ZHANG, G.; ZHAO, J.; ZHAO, C.; ZHU, F.; ZHU, H.; ZHU, S.; ZOU, S. 2016. Microsatellite records for volume 8, issue 1. Conservation Genetics Resources, 8(1): 43-81. http://dx.doi. org/10.1007/s12686-016-0522-2.

ASHIKAGA, F.Y., ORSI, M.L., OLIVEIRA, C., SENHORINI, J.A. and FORESTI, F., 2015. The endangered species Brycon orbignyanus: genetic analysis and definition of priority areas 
for conservation. Environmental Biology of Fishes, vol. 98, no. 7, pp. 1845-1855. http://dx.doi.org/10.1007/s10641-015-0402-8.

ATTARD, C.R.M., MÖLLER, L.M., SASAKI, M., HAMMER, M.P., BICE, C.M., BRAUER, C.J., CARVALHO, D.C., HARRIS, J.O. and BEHEREGARAY, L.B., 2016. A novel holistic framework for genetic-based captive-breeding and reintroduction programs. Conservation Biology, vol. 30, no. 5, pp. 1060-1069. http://dx.doi. org/10.1111/cobi.12699. PMid:26892747.

CARMO, F.M., POLO, É.M., SILVA, M.A. and YAZBECK, G.M., 2015. Optimization of heterologous microsatellites in piracanjuba. Pesquisa Agropecuária Brasileira, vol. 50, no. 12, pp. 1236-1239. http://dx.doi.org/10.1590/S0100-204X2015001200015.

CASTRO, P.L., RIBEIRO, R.P., SANTOS, S.C.A., GOES, E.S.R., SOUZA, F.P., POVEDA-PARRA, A.R., VARGAS, L., URREA-ROJAS, A.M. and LOPERA-BARRERO, N.M. 2017. Cross-amplification of heterologous microsatellite markers in Piracanjuba. Ciência Rural, vol. 47, no. 12, e20170374. http:// dx.doi.org/10.1590/0103-8478cr20170374.

GREEN, M.R. and SAMBROOK, J., 2012. Molecular cloning: a laboratory manual. 4th ed. Cold Spring Harbor: CSHL Press. $2028 \mathrm{p}$.

LOPERA-BARRERO, N.M., 2009. Conservation of Brycon orbignyanus natural populations and stocks for their reproductive, genetic, environmental sustainability: a model for species threatened with extinction. Ciencia e Investigación Agraria, vol. 36, no. 2, pp. 191-208. http://dx.doi.org/10.4067/S0718-16202009000200004.

LOPERA-BARRERO, N.M., ALVAREZ, C.A.R., RODRIGUEZRODRIGUEZ, M.P., POVH, J.A., VARGAS, L., STREIT JÚNIOR, D.P.S., SIROL, R.N. and RIBEIRO, R.P., 2014. Genetic diversity and paternity of Brycon orbignyanus offspring obtained for different reproductive systems. Ciências Agrárias, vol. 35, no. 1, pp. 541-554. http://dx.doi.org/10.5433/1679-0359.2014v35n1p541.

LOPERA-BARRERO, N.M., VARGAS, L., SIROL, R.N., RIBEIRO, R.P., POVH, J.A. and MANGOLIN, C.A., 2010. Genetic characterization of Brycon orbignyanus using the seminatural system. Arquivo Brasileiro de Medicina Veterinária e Zootecnia, vol. 62, no. 1, pp. 184-191. http://dx.doi.org/10.1590/ S0102-09352010000100025.

MACHADO, A.B.M., DRUMMOND, G.M. and PAGLIA, A.P. 2008. Livro vermelho da fauna brasileira ameaçada de extinção. Brasília: Ministério do Meio Ambiente. 278 p.

NOGUEIRA, L.B., GODINHO, A.L. and GODINHO, H.P., 2014. Early development and allometric growth in hatchery-reared characin Brycon orbignyanus. Aquaculture Research, vol. 45, no. 6, pp. 1004-1011. http://dx.doi.org/10.1111/are.12041.

OLIVEIRA, D.J., ASHIKAGA, F.Y., FORESTI, F. and SENHORINI, J.A., 2017. Conservation status of the "piracanjuba" Brycon orbignyanus (Valenciennes, 1850) (Characiformes, Bryconidae): basis for management programs. Biodiversidade Brasileira, vol. 7, no. 1, pp. 18-33.

RODRIGUEZ-RODRIGUEZ, M.P., LOPERA-BARRERO, N.M., RIBEIRO, R.P., POVH, J.A., VARGAS, L., SIROL, R.N. and JACOMETO, C.B., 2010. Genetic diversity of piracanjuba used in stock enhancement programs with microsatellite markers. Pesquisa Agropecuária Brasileira, vol. 45, no. 1, pp. 56-63. http:// dx.doi.org/10.1590/S0100-204X2010000100008.

SAMARAKOON, T., WANG, S.Y. and ALFORD, M.H., 2013. Enhancing PCR amplification of DNA from recalcitrant plant specimens using a trehalose-based additive1. Applications in Plant Sciences, vol. 1, no. 1, pp. 1200236. http://dx.doi.org/10.3732/ apps. 1200236

SIPAÚBA-TAVARES, L.H., ALVAREZ, E.S. and BRAGA, F.S., 2008. Qualidade da água e zooplâncton em tanques de larvicultura de Brycon orbignyanus (Valenciennes, 1949). Brazilian Journal of Biology $=$ Revista Brasileira de Biologia, vol. 68, pp. 77-86. http:// dx.doi.org/10.1590/S1519-69842008000100011. PMid:18470380.

SHIN, G., GRIMES, S.M., LEE, H., LAU, B.T., XIA, L.C. and JI, H.P., 2017. CRISPR-Cas9-targeted fragmentation and selective sequencing enable massively parallel microsatellite analysis. Nature Communications, vol. 8, pp. 14291. http://dx.doi. org/10.1038/ncomms14291.

SOUZA, F.P., URREA-ROJAS, A.M., RUAS, C.F., POVH, J.A., RIBEIRO, R.P., RUAS, E.A., GIACOMIN, R.M., GOES, B.D., CASTRO, P.L. and LOPERA-BARRERO, N.M., 2018. Novel microsatellite markers for the endangered neotropical fish Brycon orbignyanus and cross-amplification in related species. Italian Journal of Animal Science, 1-5. https://dx.doi.org/10.1080/182 8051X.2018.1436008

UNTERGASSER, A., CUTCUTACHE, I., KORESSAAR, T., YE, J., FAIRCLOTH, B.C., REMM, M. and ROZEN, S.G., 2012. Primer3 - new capabilities and interfaces. Nucleic Acids Research, 40(15):e115. https://doi.org/10.1093/nar/gks596.

WANG, Y., ZHAO, J., LI, W., ZHANG, X., HONG, X. and ZHU, X., 2016. Development of a multiplex microsatellite PCR assay based on microsatellite markers for the mud carp, Cirrhinus molitorella. Journal of the World Aquaculture Society, vol. 47, no. 2, pp. 277-286. http://dx.doi.org/10.1111/jwas.12261.

YAZBECK, G.M., OLIVEIRA, R.S., RIBEIRO, J.M., GRACIANO, R.D., SANTOS, R.P., CARMO, F.M.S. and LAVENIER, D., 2018. A broad genomic panel of microsatellite loci from Brycon orbignyanus (Characiformes: Bryconidae) an endangered migratory Neotropical fish. Scientific Reports, vol. 8, no. 1, pp. 8511. http:// dx.doi.org/10.1038/s41598-018-26623-x. PMid:29855493.

YUE, G.H. and XIA, J.H., 2014. Practical considerations of molecular parentage analysis in fish. Journal of the World Aquaculture Society, vol. 45, no. 2, pp. 89-103. http://dx.doi. org/10.1111/jwas.12107. 